\title{
A Turner syndrome case associated with $\operatorname{dic}(Y ; 22)$
}

\author{
Rie Kawamura ${ }^{1}$, Hidehito Inagaki ${ }^{1}$, Midori Yamada², Fumihiko Suzuki ${ }^{1}$, Yuki Naru ${ }^{1}$ and Hiroki Kurahashi ${ }^{*}$
}

\begin{abstract}
Background: Constitutional telomeric associations are very rare events and the mechanism underlying their development is not well understood.

Case presentation: We here describe a female case of Turner syndrome with a 45,X,add(22)(p11.2)[25]/45,X[5]. We reconfirmed this karyotype by FISH analysis as 45,X,dic(Y;22)(p11.3;p11.2)[28]/45,X[2].ish dic(Y;22)(SRY+,DYZ1+). A possible mechanism underlying this mosaicism was a loss of dic(Y;22) followed by a monosomy rescue of chromosome 22. However, SNP microarray analysis revealed no loss of heterozygosity $(\mathrm{LOH})$ in chromosome 22, although a mosaic pattern of $\mathrm{LOH}$ was clearly detectable at the pseudoautosomal regions of the sex chromosomes.
\end{abstract}

Conclusions: Our results suggest that the separation of the dicentric chromosome at the junction resulted in a loss of chromosome $Y$ without a loss of chromosome 22, leading to this patient's unique mosaicism. Although telomere signals were not detected by FISH at the junction, it is likely that the original dic(Y;22) chromosome was generated by unstable telomeric associations. We propose a novel "pulled apart" mechanism as the process underlying this mosaicism.

Keywords: Telomeric associations, Turner syndrome, $\operatorname{dic}(\mathrm{Y}, 22)$

\section{Background}

Telomeres are highly specialized structures that protect the ends of chromosomes and thereby prevent endto-end fusions with other chromosomes. The loss of telomere function can lead to dicentric chromosomes as a result of end-to-end fusions, a phenomenon referred to as telomeric associations (TAs) [1]. Constitutional TAs are very rare events however [2-5]. Only about 10 cases of TAs between two autosomal chromosomes have been reported to date, all preferentially involving acrocentric chromosomes. Cases with TAs involving an autosome and chromosome $\mathrm{Y}$ have been occasionally reported. Cases of constitutional TAs between an autosome and

\footnotetext{
*Correspondence: kura@fujita-hu.ac.jp

${ }^{1}$ Division of Molecular Genetics, Institute for Comprehensive Medical Science, Fujita Health University, 1-98 Dengakugakubo, Kutsukake-cho, Toyoake-shi, Aichi 470-1192, Japan

Full list of author information is available at the end of the article
}

chromosome $\mathrm{Y}$ have been generally reported as a mosaicism of two cell lines: a line with an end-to-end fusion of the $\mathrm{Y}$ and autosomal chromosomes, resulting in a dicentric chromosome, and a line whereby the dicentric chromosomes have been separated from each other and only the $Y$ chromosome is lost $[3,5]$. It is possible that the repeated TAs between an autosome and Y chromosome described in prior reports have been based on the recognizable Turner syndrome phenotype arising after the loss of the $\mathrm{Y}$ chromosome. The common feature of these cases is that the dicentric chromosomes are separated from each other, but the underlying mechanism of their development is not well understood. In our present case report, we present a detailed cytogenetic and genomic analysis of a female patient with Turner syndrome harboring a 45,X,dic(Y;22) and 45, $\mathrm{X}$ mosaicism and propose a novel "pulled apart" mechanism as the underlying process. original author(s) and the source, provide a link to the Creative Commons licence, and indicate if changes were made. The images or other third party material in this article are included in the article's Creative Commons licence, unless indicated otherwise in a credit line to the material. If material is not included in the article's Creative Commons licence and your intended use is not permitted by statutory regulation or exceeds the permitted use, you will need to obtain permission directly from the copyright holder. To view a copy of this licence, visit http://creativecommons.org/licenses/by/4.0/. The Creative Commons Public Domain Dedication waiver (http://creativeco mmons.org/publicdomain/zero/1.0/) applies to the data made available in this article, unless otherwise stated in a credit line to the data. 


\section{Case presentation}

Our current study patient was a girl of short stature with no notable external malformations other than a short neck. Cytogenetic analysis of her peripheral blood cells at the age of 13 revealed a $45, \mathrm{X}, \operatorname{add}(22)(\mathrm{p} 11.2)[25] / 45, \mathrm{X}[5]$. She responded well to growth hormone therapy which commenced when she entered high school. After receiving approval from the Ethics Review Board for Human Genome Studies at Fujita Health University, and written informed consent from the patient's parents, to allow her participation in our study, subsequent cytogenetic analyses were performed to identify the origin of the add(22) and gain insights into the underlying developmental mechanism. Since a Y chromosome was found in our patient, she underwent a gonadectomy to prevent gonadoblastoma. With regard to the patient's internal genitalia, she had a hypoplastic uterus and organs that appeared to be ovaries and fallopian tubes at their expected location. Histopathologically, the ovaries and fallopian tubes were normal with no testicular tissue or tumor. She has been continued on estrogen therapy and is being followed as a female.

\section{Methods and results}

We carried out G-band reanalysis and metaphase FISH analysis using peripheral blood cells from the patient (Additional file 1: Fig. 1). The FISH probes were specific for chromosome Y (SRY, DYZ1) (Cytocell, lnc., Cambridge, UK). By re-karyotyping using FISH analysis with an SRY probe, we confirmed the patient's karyotype as $\operatorname{mos} 45, \mathrm{X}, \operatorname{dic}(\mathrm{Y} ; 22)(\mathrm{p} 11.3 ; \mathrm{p} 11.2)[28] / 45, \mathrm{X}[2]$.ish $\operatorname{dic}(\mathrm{Y} ; 22)$ (SRY+,DYZ1+). We increased the number of cells to 100 metaphases for G-banding and 200 interphase nuclei for FISH analyses and examined the mosaic ratio of two cell lines. It was concluded that the $\operatorname{dic}(\mathrm{Y} ; 22)$ and $45, \mathrm{X}$ cells represented $85-92 \%$ and $8-15 \%$, respectively, of the population (Additional file 2: Fig. 2).

We also conducted SNP microarray analysis using a CytoScan HD Array (Affymetrix, Santa Clara, CA) to investigate how the patient's mosaicism had been generated. Briefly, genomic DNA was extracted from her peripheral blood cells using a Gentra Puregene Blood kit (Qiagen, Hilden, Germany). Sample preparation was performed in accordance with the manufacturer's protocol. The array scan data were visualized using ChAS 3.2 software (Affymetrix). The signals from the Y chromosome copy number probe were slightly lower than the normal 46,XY control, indicating a low level mosaicism of an entire Y chromosome loss (Fig. 1A). Accordingly, the SNP probes located in the pseudoautosomal region (PAR) revealed a mosaic pattern with 1 and 2 copies. In the normal 46, XY control, the $\mathrm{B}$ allele frequency (BAF) plots of PAR1 indicated AA, AB, BB SNP-genotypes. In our study patient however, the BAF of PAR1 showed an $\mathrm{AA} / \mathrm{A}, \mathrm{AB} / \mathrm{A}, \mathrm{AB} / \mathrm{B}, \mathrm{BB} / \mathrm{B}$ mosaic pattern (Fig. 1B). In contrast, no copy number change or loss of heterozygosity (LOH) on chromosome 22 was detected (Fig. 1C). The BAF standard deviation for $\mathrm{AB}$ heterozygous probes on chromosome 22 was compared to other all autosomes and to the PAR on chromosome $\mathrm{X}$. The standard deviation of the AB BAF plots on the PAR was 0.08 , whereas that on all autosomes including chromosome 22 was 0.03 (Additional file 3: Fig. 3).

Based on our microarray data, we deemed that a loss of $\operatorname{dic}(\mathrm{Y} ; 22)$ followed by a monosomy rescue of chromosome 22 was unlikely. Instead, we speculated that a separation of the dicentric chromosome at the junction resulted in the loss of chromosome $\mathrm{Y}$ without the loss of chromosome 22, leading to this patient's unique mosaicism. Since it was possible that the original $\operatorname{dic}(\mathrm{Y} ; 22)$ chromosome was generated by unstable TA, FISH was performed using telomeric and subtelomeric probes. As expected, chromosome 22 and chromosome $\mathrm{Y}$ were found to be joined between the short arms, and rDNA and $\beta$-satellite signals on 22pter, and a Ypter signal were observed between each centromere of $\operatorname{dic}(\mathrm{Y} ; 22)$. However, no telomere signal was observed (Fig. 2). On both of the chromosomes 22 in the $45, \mathrm{X}$ cell line, rDNA and $\beta$-satellite signals were confirmed, whereas signals originating from the $\mathrm{Y}$ chromosome were not observed.

\section{Discussion}

We here report a patient with possible TA between chromosomes $\mathrm{Y}$ and 22 manifesting a Turner syndrome phenotype. Four cases with TAs involving an autosome and chromosome $\mathrm{Y}$ have been reported to date (Table 1) [3$5,13]$. All of these prior cases involve a mosaicism of cell lines with TA and with 45,X, suggesting the instability of the TA chromosome, resulting in a Y chromosome loss. Notably, two previous cases showed a jumping translocation-like karyotype, in which two independent cell lines were produced, each carrying TA between the Y chromosome and different autosomes. One case showed tas $(\mathrm{Y} ; 8)$ and $\operatorname{tas}(\mathrm{Y} ; 16)$ in the peripheral blood, whereas the other harbored $\operatorname{tas}(\mathrm{Y} ; 21)$ in peripheral blood but $\operatorname{tas}(\mathrm{Y} ; 14)$ was identified in the gonadal tissue in addition to $\operatorname{tas}(\mathrm{Y} ; 21)[4$, 13]. These observations also suggested the instability of TA chromosomes.

There were two possible developmental mechanisms for the mosaic karyotypes in our current study case harboring a 45,X,dic( $\mathrm{Y} ; 22) / 45, \mathrm{X}$ karyotype. One was a loss of $\operatorname{dic}(\mathrm{Y} ; 22)$ followed by a monosomy rescue of chromosome 22 (Fig. 3A, top), and the other was a $\operatorname{dic}(\mathrm{Y} ; 22)$ separation at the junction followed by a loss of chromosome Y (Fig. 3A, bottom). We concluded that endoduplication of chromosome 22 was unlikely in our current case since 


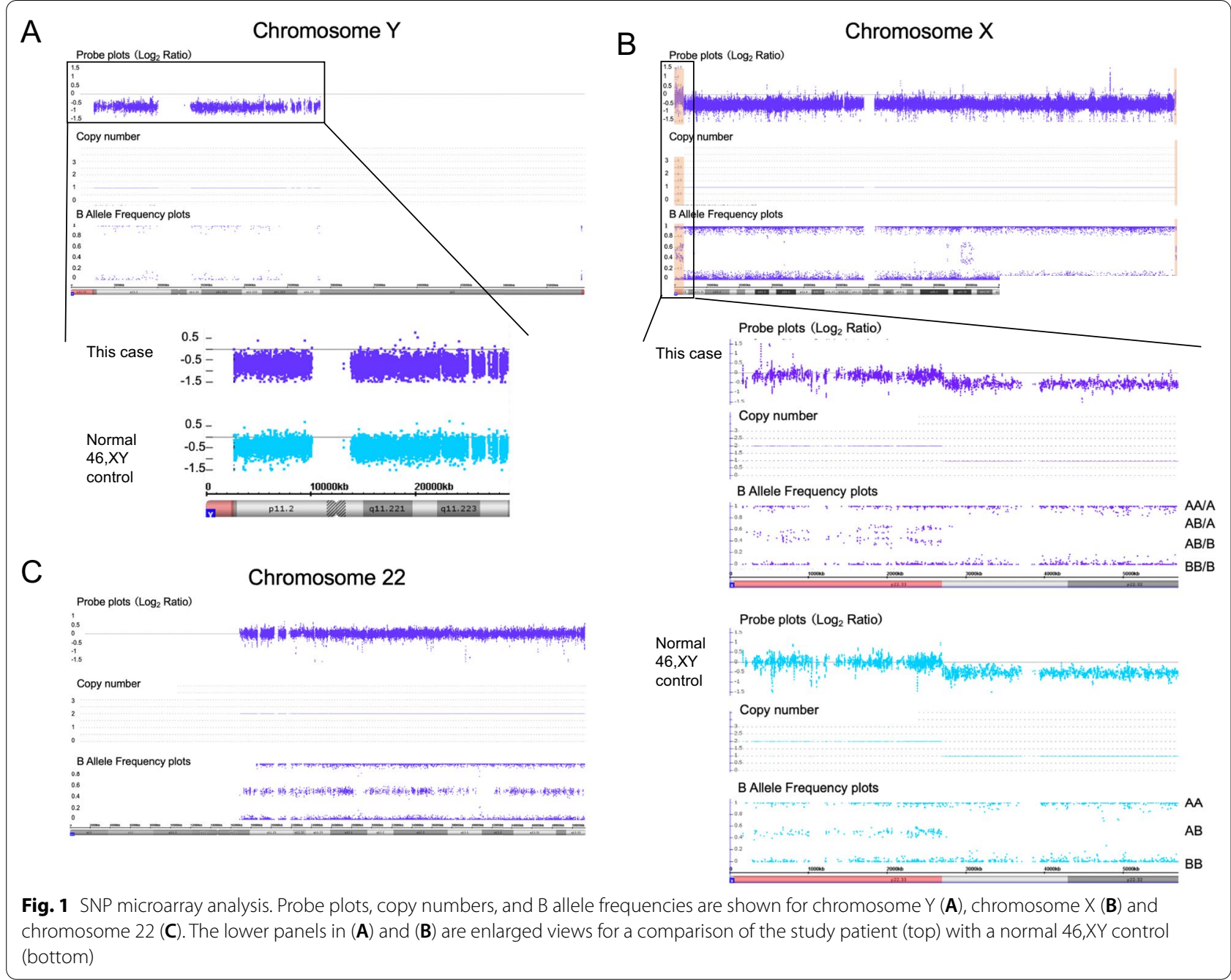

the SNP microarray results showed no evidence of low $\mathrm{LOH}$ levels on chromosome 22 . These data strongly suggested instead that chromosomes $\mathrm{Y}$ and 22 were separated at the junction of $\operatorname{dic}(\mathrm{Y} ; 22)$ and that chromosome $\mathrm{Y}$ was lost shortly after that breakage took place (Fig. 3A, bottom). Thus, we speculated from our current findings for this patient that the original $\operatorname{dic}(\mathrm{Y} ; 22)$ chromosome was generated by unstable TAs. Since similar SNP microarray data were also previously reported for tas $(Y ; 7)$, the mosaicism in our present patient is likely to have arisen via the latter process [3]. We hereby propose a novel "pulled apart" mechanism which is caused by TA fragility and that leads to this unique mosaicism.

Exposed telomere ends are generally recognized as DNA breaks by the DNA repair system, and thereby joined to other DNA breaks by end-to-end fusion via non-homologous end joining (NHEJ). If the telomeres are sufficiently long however, the DNA ends may form a secondary structure known as a telomere T-loop which will be shielded from a DNA repair reaction with the aid of a protein complex called shelterin. TAs can take place if this protection is impaired. The telomeres shorten with each successive chromosome replication and cell division cycle $[6,7]$. When this shortening reaches a certain point with aging, the protective response from T-loop formation can become less effective and TAs can be generated. Thus, the telomere sequence at the junction of a TA may be too short to be detectable by telomere FISH. Notably in this regard, some reported TA cases show positive telomere FISH signals while others do not $[3,5]$.

A still unresolved question with regard to our current case is why the breakage occurred at the junction and the two chromosomes were separated again. When telomeres recombine with each other through NHEJ, they are predicted to form inverted repeats, i.e. palindromic sequences, which may then form a cruciform structure (Fig. 3B). Such palindromic sequences have been often identified at the breakpoints of constitutional 

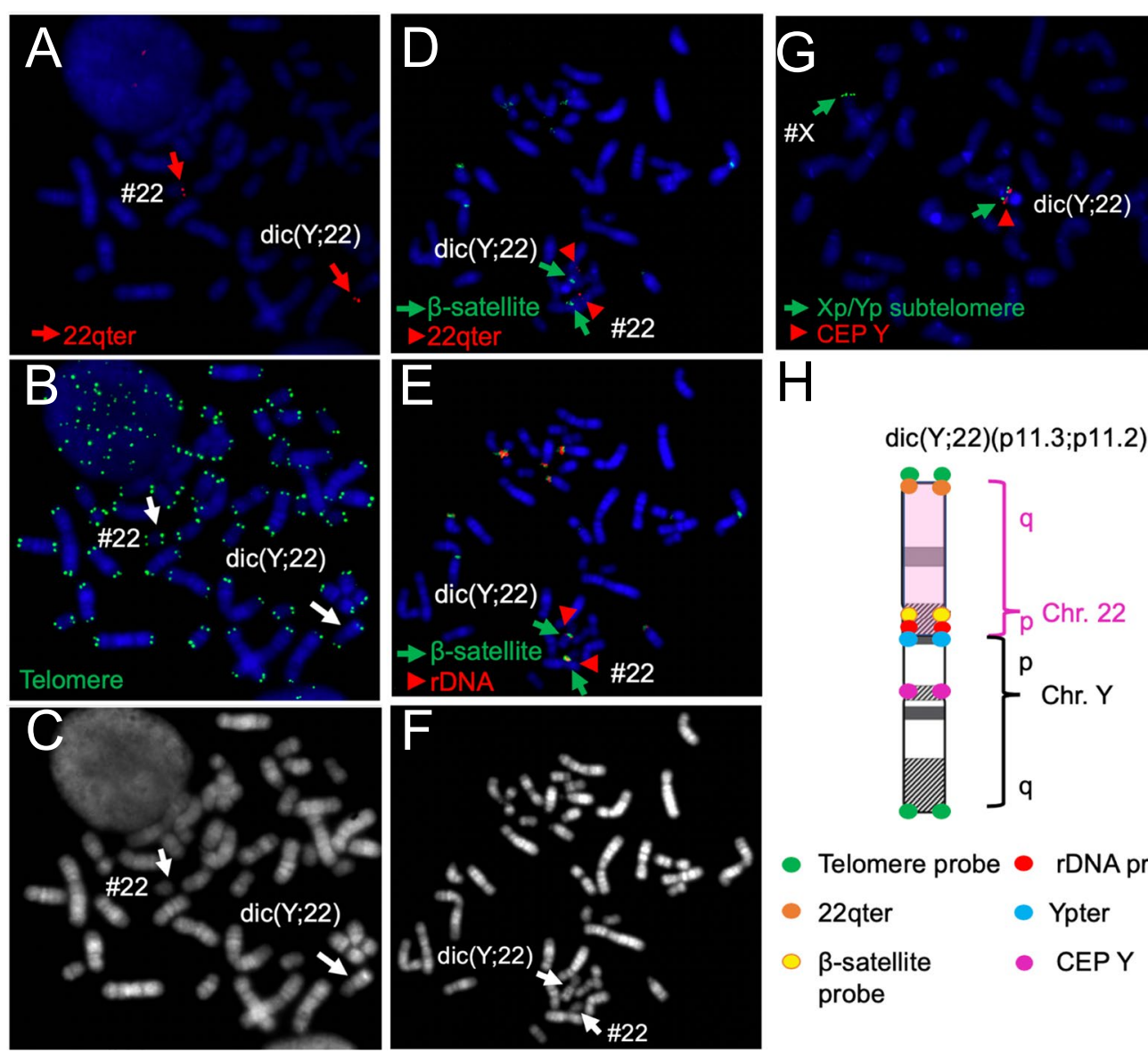

\section{$\mathrm{H}$}

$\operatorname{dic}(\mathrm{Y} ; 22)(\mathrm{p} 11.3 ; \mathrm{p} 11.2)$
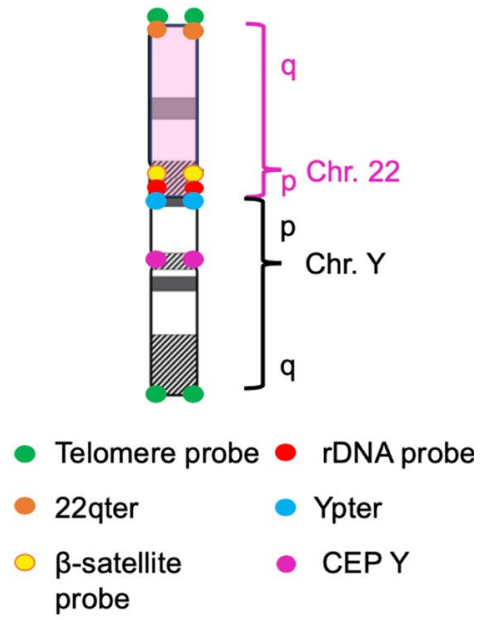

Fig. 2 FISH analysis. The results shown in (A-C) are from the same metaphase as are those indicated in (D-F). (A) Probing of the subtelomeric region of chromosome 22q (red). (B) Probing of telomeric regions (green). The white arrows denote chromosome 22 and dic(Y;22). (C) FISH inverted DAPI image of (A). (D) Probing of the $\beta$-satellite region (green), and subtelomeric region of chromosome 22q (red). (E) Probing of the $\beta$-satellite region (green), and rDNA region (red). (F) FISH inverted DAPI image of (E). (G) Probing of the subtelomeric regions of chromosome Xp and Yp (green), and the centromeric region of chromosome $Y$ (red). (H) Schema for the FISH analysis of $\operatorname{dic}\left(Y_{;} 22\right)$

Table 1 Summary of previously published TA cases

\begin{tabular}{lllll}
\hline Chromosome abnormality in the blood & Cell proportions (\%) & $\begin{array}{l}\text { Chromosome } \\
\text { loss in 45, } \mathbf{l}\end{array}$ & Clinical features & References \\
\hline $45, X / 46, X, \operatorname{tas}(Y ; 7)$ & $Y$ & Gonadal dysgenesis & Beneteau et al. [3] \\
$45, X / 46, X, \operatorname{tas}(Y ; 16) / 46, X, \operatorname{tas}(Y ; 8)$ & $3 / 97$ & $Y$ & Ambiguous genitalia & Zhang et al. [4] \\
$45, X / 46, X, \operatorname{tas}(Y ; 19)$ & $40 / 40 / 20$ & $Y$ & Premature ovarian insufficiency & Barnabas et al. [5] \\
$45, X / 46, X, \operatorname{tas}(Y ; 21)^{*}$ & $33 / 67$ & $Y$ & Turner syndrome & Sawyer et al. [13] \\
$45, X / 45, X, \operatorname{dic}(Y ; 22)$ & $50 / 50$ & $Y$ & Turner syndrome & Present case \\
\hline
\end{tabular}

*The left gonadal tissue of this patient showed an evolution of 2 additional cell lines i.e. $45, X, \operatorname{tas}(Y ; 21)(q 12 ; p 13),-22 / 46, X, \operatorname{tas}(Y ; 21)(q 12 ; p 13),+\operatorname{tas}(Y ; 14)(q 12 ; p 13),-22$

translocations in humans, the best studied example of which is $\mathrm{t}(11 ; 22)[8,9]$. Such an unstable DNA secondary structure would be a target for DNA cleavage enzymes, thus leading to the recurrent translocation [9]. In this context, TA cases may always have a risk of secondary rearrangements, including jumping translocations [10].
A considerable subset of Turner syndrome cases develop as a $45, \mathrm{X}$ mosaicism $[11,12]$. Previously reported cases involving TAs between the $\mathrm{Y}$ chromosome and the autosomes manifested a phenotype involving a mixed gonadal dysgenesis due to Y chromosome loss (Table 1) $[3-5,13]$. Since the mosaic ratio varies among patients, 


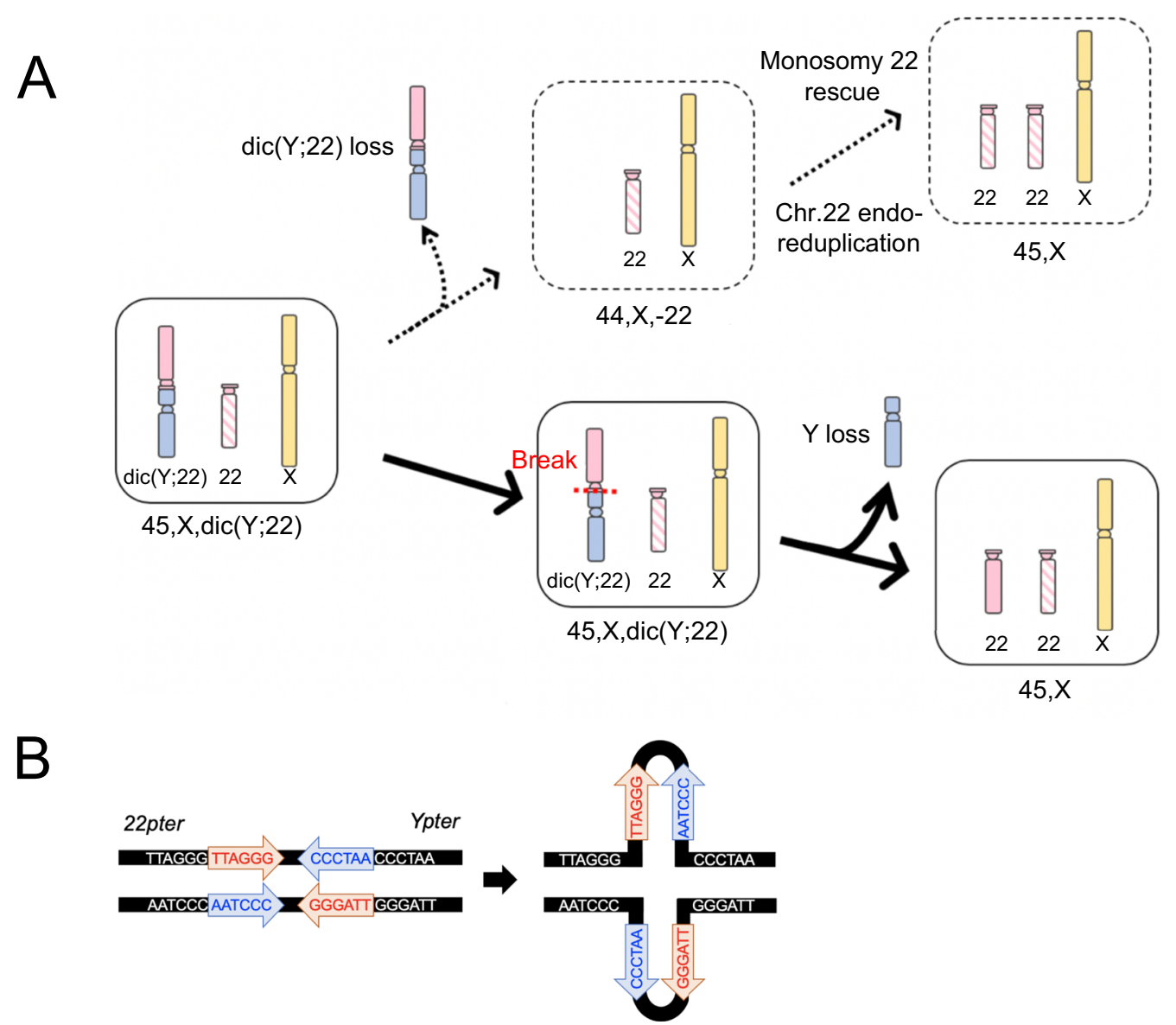

Fig. 3 Possible mechanisms underlying the mosaicism in the study patient. (A) One hypothesis for the mechanism underlying the study patient's karyotype is that a $\operatorname{dic}(\mathrm{Y} ; 22)$ loss was followed by endo-reduplication of the remaining normal chromosome 22 (upper diagram). Alternatively, $\operatorname{dic}(Y ; 22)$ may have undergone a break at the junction followed by loss of the $Y$ segment and telomere healing at 22p (lower diagram). (B) Predicted secondary structure following end-to-end telomere fusion. The resulting palindromic sequences have the potential to form a cruciform structure via intrastrand-base pairing of single-stranded DNA. The sequences indicated by red arrows are complementary to those indicated by blue arrows

and also varies from tissue to tissue, some cases manifested mixed gonadal dysgenesis and others manifested a Turner phenotype. It is well documented that the coexistence of cells with and without a Y chromosome in the same gonads indicates a high risk of gonadoblastoma. Since there is a high risk of gonadoblastoma in Turner syndrome patients involving the $\mathrm{Y}$ chromosome [14], our current patient underwent a gonadectomy and fortunately no evidence of gonadoblastoma was detected. Turner syndrome cases carrying a mosaicism due to TAs between the Y chromosome and autosome should always receive preventative treatment for possible gonadoblastoma.

\section{Conclusions}

The mechanism underlying the development of the $45, \mathrm{X}, \operatorname{dic}(\mathrm{Y} ; 22)$ and $45, \mathrm{X}$ mosaicism identified in our present Turner syndrome patient may have been due to the fragility caused by TAs. If we analyze the structure around the junction at the sequence level using a longread sequencer, we might in the future be able to elucidate the mechanism of TA development in more detail.

\begin{abstract}
Abbreviations
FISH: fluorescence in situ hybridization; LOH: loss of heterozygosity; TAs: telomeric associations; SNP microarray: single nucleotide polymorphism microarray; PAR: pseudoautosomal region; BAF: B allele frequency; NHEJ: non-homologous end joining.
\end{abstract}

\section{Supplementary Information}

The online version contains supplementary material available at https://doi. org/10.1186/s13039-021-00556-z.

Additional file 1. Fig. $1 \mathrm{G}$-banding analysis of the study patient

Additional file 2. Fig. 2 Mosaic ratio results 
Additional file 3. Fig. 3 BAF standard deviation for AB heterozygous probes

\section{Acknowledgements}

We thank the patient and her family for participating in this study.

This article belongs to the Topical Collection: Mosaicism and Chromosome-Genome Instability.

\section{Authors' contributions}

Study concepts: RK, HI, HK; Collection of patient data: MY; karyotyping and interpretation: FS, YN, HK; SNP microarray analysis and interpretation: HI, RK, HK; FISH analysis and interpretation: RK, HK; manuscript preparation: RK, HK. All authors read and approved the final version of the manuscript.

\section{Funding}

This work was supported by JSPS KAKENHI Grant Number JP17K00481.

\section{Availability of data and materials}

Please contact the corresponding author regarding any data requests.

\section{Declarations}

\section{Ethics approval and consent to participate}

This study was approved by Fujita Health University Ethics Committee. Written informed consent was obtained from the parents of the patient of this study.

\section{Consent for publication}

Written informed consent was obtained from the parents of the patient to publish the data presented in this study.

\section{Competing interests}

The authors declare no financial or other competing interests in relation to this article

\section{Author details}

'Division of Molecular Genetics, Institute for Comprehensive Medical Science, Fujita Health University, 1-98 Dengakugakubo, Kutsukake-cho, Toyoake-shi, Aichi 470-1 192, Japan. ${ }^{2}$ Kariya Toyota General Hospital, Pediatrics, 5-15, Sumiyoshi-cho, Kariya-shi, Aichi 448-0000, Japan.

Received: 31 March 2021 Accepted: 29 June 2021

Published online: 08 July 2021
2. Huang B, Martin CL, Sandlin CJ, Wang S, Ledbetter DH. Mitotic and meiotic instability of a telomere association involving the $Y$ chromosome. Am J Med Genet A. 2004:129:120-3.

3. Beneteau C, Baron S, David A, Jossic F, Poulain D, Schmitt S, et al. Constitutional telomeric association $(Y ; 7)$ in a patient with a female phenotype. Am J Med Genet A. 2013;161:1436-41.

4. Zhang L, Cooley LD, Chandratre SR, Ahmed A, Jacobson JD. A newborn with genital ambiguity, 45,X/46,XY mosaicism, a jumping chromosome $Y$, and congenital adrenal hyperplasia. Case Rep Endocrinol. 2013. https:// doi.org/10.1155/2013/747898.

5. Barnabas LC, Shankar K, Kar B. Telomeric association between chromosomes $Y$ and 19 in a mosaic Turner with primary ovarian insufficiency. J Obstet Gynaecol Res. 2019;45:2293-6.

6. Maser RS, DePinho RA. Connecting chromosomes, crisis, and cancer. Science. 2002;297:565-9.

7. Murnane JP. Telomere dysfunction and chromosome instability. Mutat Res. 2012;730:28-36.

8. Kurahashi $\mathrm{H}$, Inagaki $\mathrm{H}$, Ohye $T$, Kogo $\mathrm{H}$, Tsutsumi M, Kato T, et al. The constitutional t(11;22): implications for a novel mechanism responsible for gross chromosomal rearrangements. Clin Genet. 2010;78:299-309.

9. Inagaki H, Ohye T, Kogo H, Kato T, Bolor H, Taniguchi M, et al. Chromosomal instability mediated by non-B DNA: cruciform conformation and not DNA sequence is responsible for recurrent translocation in humans. Genome Res. 2009;19:191-8.

10. Tsutsumi M, Fujita N, Suzuki F, Mishima T, Fujieda S, Watari M, et al. A constitutional jumping translocation involving the $Y$ and acrocentric chromosomes. Asian J Androl. 2019;21:101-3.

11. Vorsanova SG, Kolotii AD, Kurinnaia OS, Kravets VS, Demidova IA, Soloviev IV, et al. Turner's syndrome mosaicism in girls with neurodevelopmental disorders: a cohort study and hypothesis. Mol Cytogenet. 2021;14:9. https://doi.org/10.1186/s13039-021-00529-2.

12. Graff A, Donadille B, Morel H, Villy MC, Bourcigaux N, Vatier C, et al. Added value of buccal cell FISH analysis in the diagnosis and management of Turner syndrome. Hum Reprod. 2020;35:2391-8.

13. Sawyer JR, Swanson CM, Lukacs JL, Hassed SJ, Curtis MA, North PE, et al. Telomeric fusion and chromosome instability in multiple tissues of a patient with mosaic Ullrich-Turner syndrome. Am J Med Genet. 1997;69:383-7.

14. Gursoy S, Ercal D. Turner syndrome and its variants. J Pediatr Res. 2017:4:171-5

\section{Publisher's Note}

Springer Nature remains neutral with regard to jurisdictional claims in published maps and institutional affiliations.

\section{References}

1. Schwartz HS, Allen GA, Butler MG. Telomeric associations. Appl Cytogenet. 1990;16:133-7.

Ready to submit your research? Choose BMC and benefit from:

- fast, convenient online submission

- thorough peer review by experienced researchers in your field

- rapid publication on acceptance

- support for research data, including large and complex data types

- gold Open Access which fosters wider collaboration and increased citations

- maximum visibility for your research: over 100M website views per year

At BMC, research is always in progress.

Learn more biomedcentral.com/submissions 